\title{
Kernos
}

Revue internationale et pluridisciplinaire de religion grecque antique

12 | 1999

Varia

\section{Fr. GRAF (éd.), Ansichten griechischer Rituale}

\section{Vinciane Pirenne-Delforge}

Fr. Graf (éd.)

\section{(2) OpenEdition}

Journals

Édition électronique

URL : http://journals.openedition.org/kernos/733

DOI : $10.4000 /$ kernos.733

ISSN : 2034-7871

Éditeur

Centre international d'étude de la religion grecque antique

\section{Édition imprimée}

Date de publication : 1 janvier 1999

Pagination : 307

ISSN : 0776-3824

\section{Référence électronique}

Vinciane Pirenne-Delforge, «Fr. GRAF (éd.), Ansichten griechischer Rituale », Kernos [En ligne], 12| 1999, mis en ligne le 13 avril 2011, consulté le 11 mars 2021. URL : http://journals.openedition.org/kernos/ 733 ; DOI : https://doi.org/10.4000/kernos.733 
diversité même d'une grande richesse; il montre aux historiens des religions ce que peuvent apporter les sources les plus diverses pour l'étude d'une période qui est largement pré-littéraire.

Madeleine Jost

(Paris X-Nanterre)

Fritz GraF (éd.), Ansichten griechischer Rituale. Geburtstags-Symposium für Walter Burkert. Castelen bei Basel 15. bis 18. März 1996, Leipzig, Teubner, 1998.1 vol. $16 \times 24 \mathrm{~cm}$, vi+467 p., 39 fig. ISBN : 3-519-07433-8.

Célébrer Walter Burkert, c'est fêter un savant qui a profondément marqué les études sur la religion grecque antique ces trente dernières années, avec des apports fondamentaux sur le rituel, et le sacrifice en particulier. C'est donc autour de ses thèmes de prédilection que se noue ce recueil articulé en quatre grandes parties.

La première (Grundlagen und Reflexionen) aborde les notions de "religion », de «rituel», de «sacré » et de «profane» dans une remarquable perspective historiographique (J.N. Bremmer), et les problèmes touchant à la compréhension difficile du rituel grec au sens large, avec l'accent porté in fine sur l'Homo Necans de Burkert (A. Henrichs). Une étude sur la figuration de scènes violentes dans la céramique attique entre 550 et 450 av. J.-C., intéressante du point de vue de la sacralisation et de la ritualisation de la terreur, termine cette partie ( $\mathrm{P}$. Blome).

La deuxième partie (Riten in der Geschichte). propose huit contributions variées, mêlant (1) un panorama du rituel dans la Grèce mycénienne (R. Hägg), (2) une (trop) brève étude sur l'iconographie et la personnalité d'Artémis (N. Marinatos), (3) une approche archéologique de la libation et de la prière gréco-romaines (E. Simon), - où l'on aurait aimé voir discutés l'article de P. Veyne (Mètis, 5 [1990], p. 17-30) et le livre de D. Aubriot (cf. Kernos, 6 [1993], p. 379-381), - (4) une approche résolument «agraire» du rituel initiatique patréen pour Artémis et Dionysos rapporté par Pausanias (G. Baudy), - qui tranche avec les interprétations anthropologiques récentes de ce type d'initiation, - (5) une excellente réévaluation du rapport entre ritus romanus et ritus graecus dans la pratique romaine (J. Scheid), (6) et une autre de la définition du taurobolion, dont la fossa sanguinis est une invention d'auteurs chrétiens (Ph. Borgeaud), (7) une analyse critique des calendes de janvier comme "fête de dissolution et de renouveau » dans l'empire romain (Fr. Graf), et enfin (8) une étude fouillée des defixiones anatomiques (H.S. Versnel).

La troisième partie rassemble trois contributions autour du thème Ritual und Tragödie, en écho au célèbre article de Burkert Greek Tragedy and Sacrificial Ritual. H. Lloyd-Jones, après une introduction personnalisée, conteste l'omniprésence, dans la tragédie, des rituels, sacrificiels ou autres, et donc la permanence des liens du genre avec ses origines anciennes. E. Krummen étudie davantage l'utilisation métaphorique du rituel par la tragédie, mais rejoint ses conclusions sur l'origine du genre. L'analyse de l'Edipe à Colone par Cl. Calame montre Sophocle réinterprétant le processus symbolique, entre «mythe » et « rite ».

La dernière partie (Orpbica et Philosophica) est centrée sur un autre domaine de prédilection de W. Burkert et aborde les questions de l'énonciation dans lamelles orphiques (Chr. Riedweg) et de l'anthropologie qui s'en dégage (H.D. Betz). Elle se referme sur une analyse de l'évolution des conceptions de la $\tau$ tún due aux dieux depuis Hésiode et les Présocratiques jusqu'à Platon et Aristote.

Vinciane Pirenne-Delforge (FNRS - Université de Liège) 